\title{
ビタミン $\mathrm{A}$ の 合 成
}

宾 戸 圭 一*

A Synthesis of Vitamin A

Keiiti SISIDO

有機合成化学協会創立 20 周年記念講演会にご招待を受 けたことは，この方面を専攻する一学徒としてまことに 光栄の至りである。偶々この機に一応の成功を得た揭題 の研究につき, その概要, 経過を述べ, ご批評, ご教示 を得たいと思ら。

ビタミンA合成の縮合反応については，すでに有機合 成化学協会誌, 17巻 257-282 ページ (昭和34年) に詳細 な解説を書かせていただいた。この研究はその後に行な ったものであるが，その間に派生した問題とあわせ，し るすことにする。

\section{I 序}

ビタミンA (以下 VA と略す) の化学構造は 1931 年 Karrer ら ${ }^{11}$ によって, 次のように定められたが $\mathrm{CH}_{3} \mathrm{CH}_{3}$

$$
\begin{array}{lll}
\mathrm{CH}=\mathrm{CH}-\mathrm{C}=\mathrm{CH}-\mathrm{CH}=\mathrm{CH}-\mathrm{C}=\mathrm{CH}-\mathrm{CH}_{2} \mathrm{OH} \\
\mathrm{CH}_{3} \quad \mathrm{CH}_{3} & \mathrm{CH}_{3}
\end{array}
$$

以来その合成について多数の研究が行なわれた。1937年 に Kuhn ら ${ }^{2)}$ がはじめて生理的活性のある製品を合成 したと報告しているが，これは追試に成功しないといら こともあり，確実にVA の全合成が成功したと認めら れるのは1956年以降のことである。その後今日まで種々 の新方法が競って発表されているけれども，現在工業的 に合成するとなると，ドイッでの方法は判らないが， 英, 米などではスイスのロッシュ社の方法に限られると いってよい3。この事実はVA 合成の有機反応がかなり の難問題を含んでおり，一見円滑に実施できそうな合成 フローシートにも，予期しない障害がいくつかひそんで いることを暗示する。

その一例としてレトロ体の生成を挙げなければなるま い。VA 合成は，いずれの方法むスミレのにおいを有 する香料 $\beta$-ヨノンを原料として進むが，それより製取

京都大学工学部（京都市左京区吉田本町）

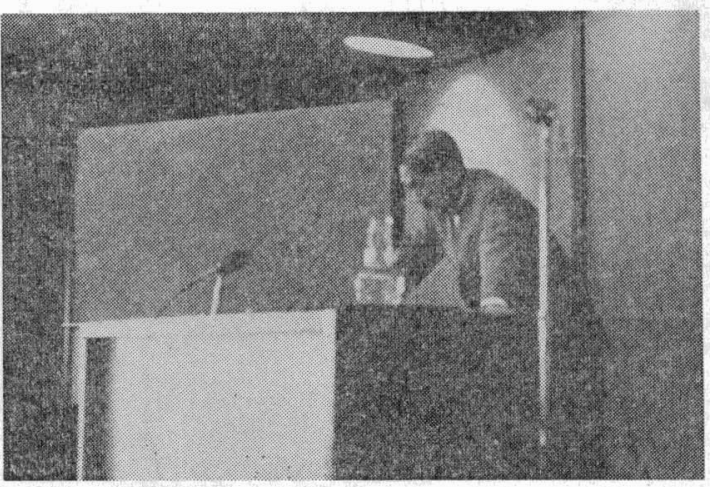

した $\beta$-ヨノール訜導体 (1) を脱水する時, 希望する前 向きの脱水生成物 (2) よりも，後向きに脱水が起ったい わゆるレトロ体 (3) を与える場合の方が多いからであ る。

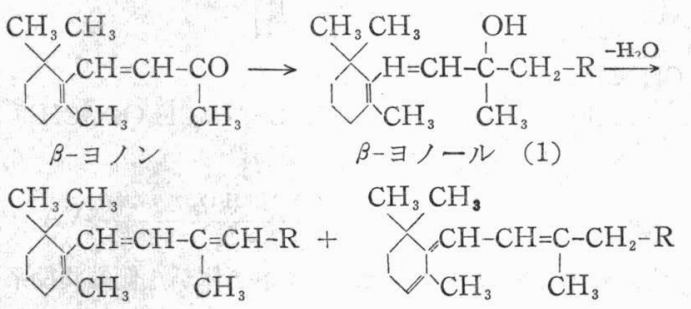

このレトロ体はVA としての活性を持たない。した がって合成に当ってはこのようなレトロ体の生成を避け ることが重要な課題となる。

Isler ら ${ }^{4)}$ の前述ロッシュ法は $\mathrm{C}_{13}$ 化合物たる $\beta$-ヨノ ンを出発物とする点，いずれの $\mathrm{VA}^{\mathrm{A}}$ 成とも同じであ るが, これを $\mathrm{C}_{14}$ 化合物とし， $\mathrm{C}_{6}$ 化合物とあわせ $\mathrm{C}_{20}$ の VA とする。この方法は巧みにレトロ体を避けるよう考 案されており，工業的成功を得ている所以であろう。詳 細については, 前の解説に述べたので, 簡易に記すが, ß-ヨノンにダルザン反応を用いてヨノン環の二重結合が 
狐立している $\beta-C_{14}$ アルデヒドとし，これにメチルビ ニルケトンとアセチレンとより合成した $\mathrm{C}_{6}$ 化合物のグ リニャール体 (4) を結びつけてジオール体とし, 三重結 合をリンドラー触媒で半還元し， 2 個ある水酸基のう ち, 第一アルコールのみをアセチル化して保護し, 最後 の脱水工程においてはじめてVA の完全な共役系に導 いている。

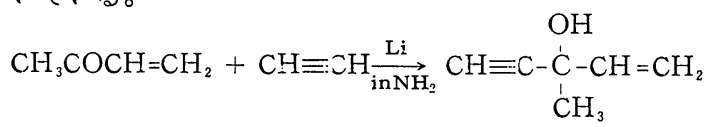$$
\underset{\text { アリル転位 }}{\stackrel{\mathrm{H}^{+}}{\longrightarrow}} \mathrm{CH} \equiv \underset{\substack{\mathrm{C} \\ \mathrm{CH}_{3}}}{\mathrm{C}}=\mathrm{CH}-\mathrm{CH}_{2} \mathrm{OH} \stackrel{2 \mathrm{C}_{2} \mathrm{H}_{5} \mathrm{MgBr}}{\longrightarrow}
$$$$
\mathrm{BrMgC} \equiv \mathrm{C}-\mathrm{C}=\mathrm{CHCH}_{2} \mathrm{OMgBr}
$$

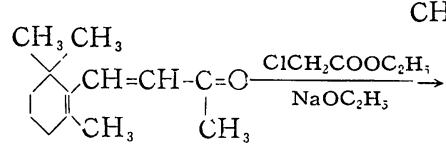$$
\text { ß-ヨノン }
$$

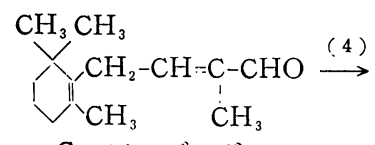

$\mathrm{C}_{14}$ アルデヒド

$\underbrace{\mathrm{CH}_{3}}_{\mathrm{CH}_{3}} \stackrel{\mathrm{CH}}{\mathrm{CH}_{3}} \stackrel{\mathrm{CH}}{\mathrm{CH}_{3}}-\mathrm{CH}-\mathrm{C}=\mathrm{CH} \cdot \mathrm{CH}_{2} \mathrm{OH}-\frac{\mathrm{CH}_{3}}{\mathrm{Pd}} \rightarrow$<smiles>CCC(C)=CCC(O)C=CC(C)CCO</smiles>
$\mathrm{CH}_{3} \mathrm{CH}_{3} \quad \mathrm{OH}$

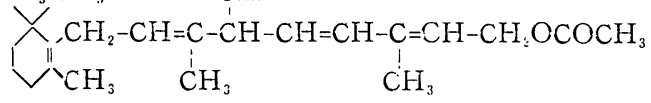

$$
\stackrel{\text { (1) } \mathrm{I}_{2},-\mathrm{H}_{2} \mathrm{O}, \text { アリル転位 }}{\rightarrow} \mathrm{VA}
$$

すなわちこの方法の特徵は，各中間体が，側鎖共役系 と環二重結合との共役が切れた化合物を用いることによ り，前述のレトロ体の生成を防ぎ，最後の脱水工程にお いてはじめて VA の高度な共役系を作り出している点 にある。

\section{II 新しい別途合成法原理}

今回の方法は $\mathrm{C}_{13}$ のヨノンに $\mathrm{C}_{2}$ のアセチレンを付け て $\mathrm{C}_{15}$ 体とし, これに $\mathrm{C}_{5}$ のツワブキ酸誘導体 (5) を 縮合させて $\mathrm{C}_{20}$ の VA にするものである。

$\mathrm{CH}_{3} \mathrm{CH}_{3}$<smiles>CCOC(=O)C=C(C)C(C)=COC#COC(C)=CCC1(C)CCCC1(C)C</smiles>

$\longrightarrow \mathrm{VA}$ 酸 $\longrightarrow \mathrm{VA}$

この場合もレトロ体の生成を防ぐには，ヨノン環と側 鎖二重結合系との共役を断ち切った化合物を用いなけれ ばならない。こうした化合物として，新規物質 $\mathrm{C}_{15}$ アセ チレン体 (6)

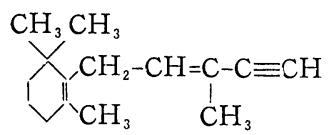

(6)

を選んだ。すなわち（6）によると，介在するメチレン基 により，側鎖と環との二重結合が孤立することとなるの， で，レトロ体ができないのである。

\section{III $r$-オキソーツワプキ酸エステルの合成}

rーオキソーツワブキ酸エチル (5) はイソプレン骨格を 有し， $\mathrm{C}_{5}$ 残基としてビタミン $\mathrm{A}$ その他のテルペノイド合 成の中間体として考がえられる興味ある化合物である。 ちなみに「ツワブキ酸」とは明治中年わが国の下山教授 がッワブキの成分として発見せられ，これを Seneciosäure英名 senecioic acid）と翻訳して発表せられたも のであり，朝比奈教授がその構造を確立せられた。この 事実を調査せず，「セネシオ酸」などと称するむきのあ るのは,まことに遺憾である。

rーオキソーツワブキ酸エステルの合成法については, すでに発表済み ${ }^{5)}$ である。それ以前の方法によると，ツ ワブキ酸（ $\beta, \beta$-ジメチルアクリル酸， $\beta$ ーメチルクロト ン酸）エステルより出発し，r-アセトキシーツワブキ酸 エステル，rーヒドロキシ酸エステルを経由して目的物に 至るのであるが，
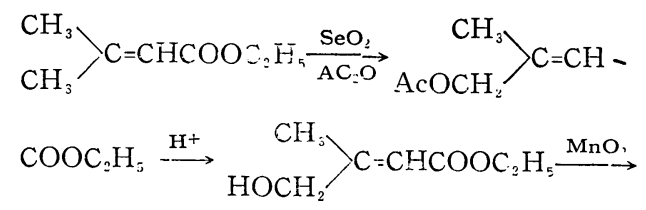

$\mathrm{H}-\mathrm{C}^{\prime \prime}$

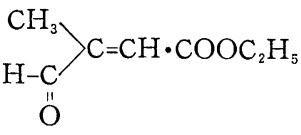

收率低く，セレン化合物の悪臭が残り，純度の高いもの は得られなかった。しかるにツワブキ酸の $r$ 位を臭素化 し，これをKröhnke 法によってアルデヒドに変えると 収量よく純品が得られることが判った。

臭素化はNーブロムーコハク酸イミドを用いるより も，高度希釈法による直接臭素化の方がよい。この臭化 物をピリジンで処理してピリニジウム塩とし, ニトロソ -ジメチルアニリンを働らかせてニトロソ体とし，それ 


\section{ビタミン $\mathrm{A}$ の合成}

(25)

を加水分解して目的物とする。

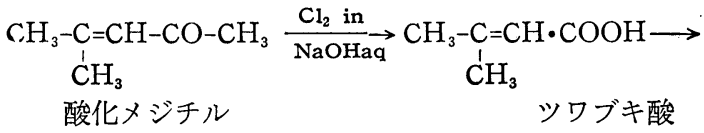

$\mathrm{CH}_{3}-\mathrm{C}=\mathrm{CHCOOC}_{2} \mathrm{H}_{5} \underset{\mathrm{CCl}_{4}}{\stackrel{\mathrm{Br}_{2} \text { in }}{\longrightarrow}} \mathrm{BrCH}_{2}-\mathrm{C}=\mathrm{CHCOOC}_{2} \mathrm{H}_{5}$ $\begin{array}{lll}\mathrm{CH}_{3} & \mathrm{CH}_{3}\end{array}$

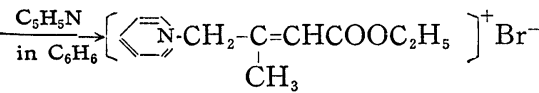

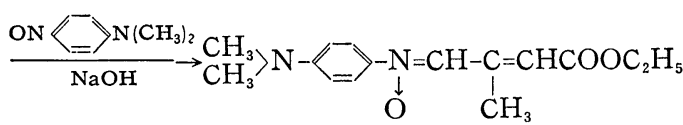

$\stackrel{\mathrm{H}_{2} \mathrm{SO}_{4}}{\rightarrow} \mathrm{O}=\mathrm{C}-\mathrm{C}=\mathrm{CH} \cdot \mathrm{COOC}_{2} \mathrm{H}_{5}$

$\mathrm{H} \quad \stackrel{1}{\mathrm{C}} \mathrm{H}_{3} \quad r$-オキソーツワブキ酸

上述のよらに従来の方法は無水亚セレン酸を使うもの であるが，それを追試した処によると，セレン化合物の 悪臭を除去することができず，本体の香気を識別するこ と不可能なものである。しかるに Kröhnke 法によった 製品は高純度であり，西瓜と全く同じ特有の芳香がある ことが見出された。本化合物はイソプレン骨格を有して おり，しかも未酸化体はツワブキ中にあるのであるか ら，西瓜本来の成分であろらかと考えて検索を試みたが 陰性であった。

\section{VI $\mathbf{C}_{15}$ アセチレン炭化水素の合成}

上述のよらに今回中閒体として使おらと考えた $\mathrm{C}_{15}$ 炭 化水素は文献末記載のものであるが，次のようにして合 成しようと試みた。

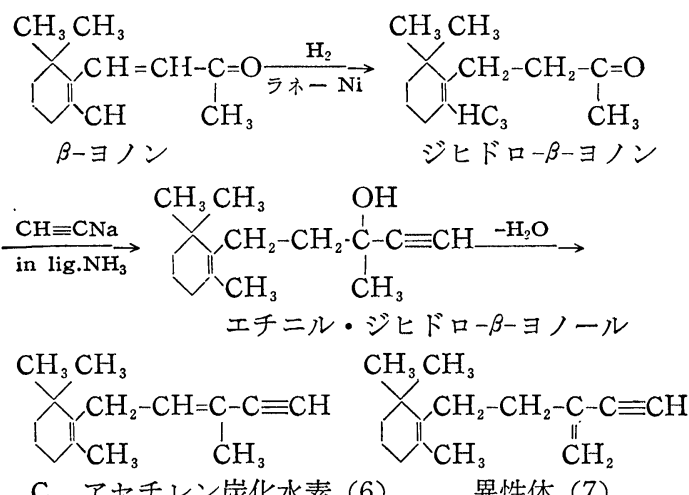

$\mathrm{C}_{15}$ アセチレン炭化水素（6）＼cjkstart異性体 (7)

以上のらちエチニルージヒドロー $\beta$-ヨノールまでは 文献記載 ${ }^{6,7)}$ のあるものであるが，脱水反応は未知であ った。

もともと三重結合に隣接する水酸基の脱水反応は $\alpha$ ヒドロキシ酸の場合と同じく, 電子吸引性のために困難 があることは周知の通りであるが，本ヨノールの場合
は，側鎖メチルの方へ脱水が起ることも考えられるので 異性体 (7) を生成する可能性があり一層複雑になる。

種々検討を行なったが，50\%硫酸，無水酶酸・硫酸， 無水リン酸, $p$ ・トルエンスルホン酸, 酸性硫酸カリ, 無 水シュウ酸などはいずれも駄目であった。またフェニル イソシアナートを用いると，ヘテロ五員環のオキサゾリ ジノンとなることが判っだ'。 リン酸アルミニウムを用 いてはじめて成功を見たが，減圧下，気相で $230^{\circ} \mathrm{C}$ 位で 反応を行なわせると，紫外，赤外，核磁気共鳴測定の結 果，(7) ではなく，(6) が得られていることが判った。

しかるにオキシ塩化リン・ピリジン法によると，ホフ マン制に従って (7) 型のメチル基の方へ脱水が起ったも. のが得られる。

$$
\text { V } \mathbf{C}_{15}+\mathbf{C}_{5} \text { 反 応 }
$$

上述の $\mathrm{C}_{15}$ アセチレン体 (6) に臭化エチルマグネシ ウムを作用させて, アセチレンの活性水素を臭化マグネ シウム基で置換し，これを $\mathrm{C}_{5}$ のオキソーツワブキ酸エ ステルと反応させる。オキソーツワブキ酸エステルはグ リニャール化合物と反応するカルボニル基 2 個を有して はいるが，アルデヒド基の方が易反応性であることを利 用し, 低温, 逆滴下法を用いて成功した。かくて得た油 状物質は赤外線吸収スペクトル測定により目的物と考え たがこれを半還元に付した。

半還元には，上述ロッシュ法にならってリンドラー触 媒も使って見たが，W6 型ラネー・ニッケルを用いた方 が好結果を挙げえた。
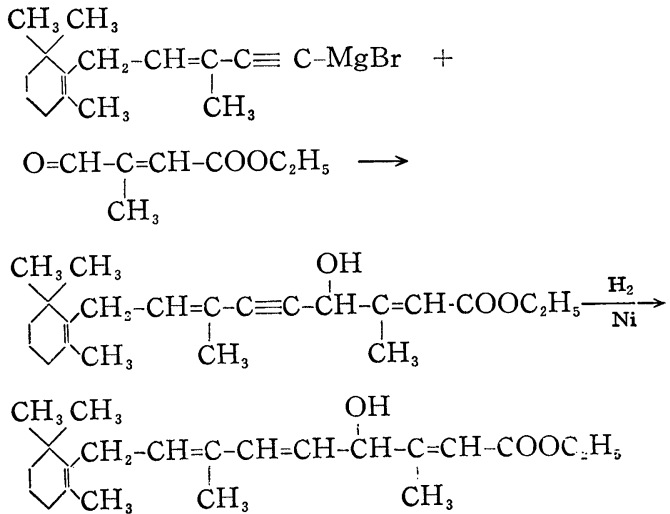
$\stackrel{\mathrm{POCl}_{2}-\mathrm{C}_{5} \mathrm{H}_{5} \mathrm{~N}}{\longrightarrow}$

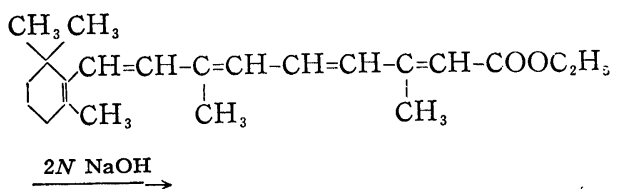




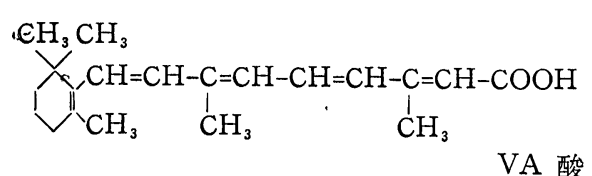

最後の工程は，かくて得られたカルビノールの脱水で ある。種々の穏和な脱水剤を試みたが, オキシ塩化リ ン・ピリジン法を用いたところ, タールを副生して黒色 油状体ができたが，そのへキサン可溶分をアルミナ・ク ロマトグラフィーにかけ, 紫外, 赤外吸収, ともに VA 酸エステルであることを示す部分を得た。これをカセイ ソーダでケン化したのにVA 酸の結晶が取れた。融点, 紫外線吸収波長, その強度より綜合して全トランス体で ある。
現在の処まだ収率がよくないので，その向上について さらに研究中である。

（昭和 37 年 9 月 25 日受理）

\section{文献}

1) Karrer,Morf, Schöpp, Helv. 14 1036, 1431 (1931)

2) Kuhn, Morris, Ber. 70853 (1937)

3) Sims, Manuf. Chem. 28128 (1957)

4) Isler et al., Helv. 301911 (1947)

5) Sisido, Kondô, Nozoki, Tuda, Udô, J. Am. Chem. Soc. 822286 (1960)

6) Naves et al., Helv. 32206 (1949)

7) Oroshnik et al., J. Am. Chem. Soc. 71.2062 (1949)

8) Sisido, Hukuoka, Tuda, Nozaki, J. Org. ${ }_{\perp} \mathrm{Clzem}$. 272663 (1962) 